\title{
THE DISPLAYS OF GENERAL TENDENCIES IN THE AREA OF ITALIAN LANGUAGE CARS TERMINOLOGY
}

\section{Jan LAVRINČÍK}

\begin{abstract}
The study deals with the significance, classification and common linguistic problem in the field of scientific and technical terminology of Italian cars and point of view on education process of common technical subject. A special attention is devoted to system terminological prefix and suffix, it argues about the present use of them with many examples.
\end{abstract}

Key words: prefix, suffix, terminology adjective, technical terminology.

\section{PROJEVY OBECNÝCH TRENDŮ V OBLASTI ITALSKÉ AUTOMOBILOVÉ TERMINOLOGIE}

Resumé: Studie se zabývá významem, klasifikací a obecnou lingvistickou problematikou v oblasti italského automobilového vědeckotechnického pojmosloví využitelného z pohledu vzdèlávacího procesu obecně technického predmětu. Osobitý důraz klade na systémové terminologické prefixy a sufixy, jejich využití se snaži objasnit na širokém spektru př́kladů.

Klíčová slova: prefix, sufix, terminologické adjektivum, technická terminologie.

\section{1 Úvod}

Technická terminologie je poměrně mladý vědní obor, jenž neustále hledá svoje autonomní místo mezi vědními disciplínami (1, s. 11). Zajímavé je její postavení na pomezí s jazykovědně profilovanými předměty a její vnitřní provázanost principů a myšlenek. Vzdělávací proces ve školních podmínkách si v podání technické terminologie žádá odlišný př́stup, jenž v sobě zahrnuje osvojení si systémových technických pojmů. Př́rodovědně orientované obory u nás mají dlouhou tradici a jejich systémy jsou ze současného pohledu velmi bohaté. Nejen věda je $z$ tohoto pohledu hlavním, ale důležitým zdrojem a vývojovým nástrojem terminologie. Sdělovací prostředky, jako např́klad rádio, televize, internet a tisk začínají získávat na důležitosti a neprímo působí na slovní zásobu jedince.

Pod komplexem uvedeným faktorů si můžeme představit širokou škálu synonymních výrazů, jež výuku často komplikují (hustota X měrná hmotnost). Časté nerespektování nesprávných pojmů terminologických systémů (špatně: umělá hmota X správně: plast). Studie se zaměřuje na zajímavou oblast automobilismu $\mathrm{v}$ technicky orientovaných předmětech $\mathrm{v}$ kombinaci $\mathrm{s}$ italskou terminologíi. Díky oblibě automobilismu a autosportu pomáhá učiteli s udržením počáteční motivace $(2$, s. 153). Největší důraz je kladen na prefixy, sufixy a terminologická adjektiva, jež ukazuje na príkladech právě $\mathrm{z}$ této oblasti. U nejfrekventovanějších prefixů a sufixů uvádí možnosti tvorby víceslovných termínů jako způsobu přssnosti pojmenování pojmů obsahem, jenž v sobě nese samotný termín $(1, \mathrm{~s}$. 27).

Studie se opírá o poznatky vědeckých statí (1), (3), (4), (5), (6) respektuje jednotný systém třídění a jejich zápisu. Hledá podobnost s českou terminologií uvedenou ve studii (4). Oblast je velmi rozmanitá díky bohaté historii automobilismu v Itálii, $\mathrm{k}$ níž nemalou měrou přispěly značky Ferrari, Fiat a Alfa Romeo. Problematice se věnuje Enzo Ferrari ve své autobiografii (7).

\section{Prefixy v italské automobilové terminologii}

Prefix představuje slovotvorný segment, jenž se připojuje před slovotvorný základ za účelem vytvoření novotvaru. Neologismy (česky novotvary) jsou nově zavedené výrazy, např. pro pojmenování skutečností, vynálezů a myšlenek. Netradičním př́íkladem je např. hrdobce (označení pro hrdého člověka). Studie $(5$, s. 801 - 802) je považuje za prostředky sloužící $\mathrm{k}$ vyjádření systémových vztahů. Vlastnost nesoucí termín, z něhož za pomoci terminologické předpony nebo př́pony vznikají termíny nové, nazývá studie (1, s. 25) jako derivativnost termínu.

anti- přepona vyjadřuje bližší časový nebo prostorový vztah s objektem zájmu nebo odpor 
proti významu substantiva $(8$, s. 52$)$; př́klady: anticipato (= předčasný start), anticipo (= předstih, náskok, pokrok, zlepšení), anticongelante (= nemrznoucí směs), antifurto (= bezpečnostní zařízení proti krádeži), antigelo (=nemrznoucí směs), antinebbia (= mlhová světla, hov. mlhovky), antiquato (= nemoderní), antiabbagliante (= potkávací světlo); víceslovný termín s anti- anticipo a mano (= ručně stavitelný předstih), anticipo automatico (= automatický předstih), sistema antiblocco $A B S$ (= protiblokovací systém $\mathrm{ABS}$ );

auto- prefix přidávající substantivu vlastnost samostatnosti a soběstačnosti nebo s neologismy souvisejícími s automobilovým názvoslovím (8, s. 60); př́lklady: autoambulanza (= sanitní vůz), autoblido (= obrněný vůz), autobotte (= cisternový vůz), autobus (= autobus), autocarro (= nákladní vůz), autocisterna (= cisternový vůz), autodromo (= automobilová závodní dráha), autofficina (= autodílna), autogru (= autojeřáb, odtahový vůz), autolavaggio (= myčka aut), automezzo (= motorové vozidlo), automobile (= automobil), autonoleggio (= půjčovna aut), autoradio (= autorádio), autorimmesa (= garáž), autostima (= autoškola), autostrada (= dálnice), autotreno (= nákladní automobil), autoveicolo (= motorové vozidlo), autovettura (= osobní automobil);

contro- prefix přidávající na dynamičnosti, pohybu nebo akci (8, s. 55); př́klady: controbilanciare (= vyvážit, vyvážení), controdado (= pojistná matice);

de- prefix jehož novotvary vedou $\mathrm{k}$ ireverzibilním stavům nebo objektům (8, s. 58); príklady: decappottabile (= auto se skládací střechou), dentato (= ozubený), deviazione (= objížd'ka, zajížd'ka); víceslovný termín s de-ruota dentata (= ozubené kolo);

dis- prefix vytváŕející opozitum k slovotvornému základu (8, s. 58); př́klady: disinnestare $(=$ odpojit vypnout, vyřadit rychlost), disturbo (= porucha);

extra- kvalitativní prefix poukazující na vysoký stupeň vlastnosti adjektiva $(8$, s. 55$)$; př́klady: extrarapido (= extrarychlý), extrasensibile (= extracitlivý);

in- prefix vyjadřující pravdivost situace nebo je opozitum k slovotvornému základu (8, s. 57); př́klady: incidente (= nehoda), incrocio $(=$ křižovatka), ingorgo (= dopravní zácpa), ingranare (= zařadit rychlost, zapadat do sebe), ingranaggio $(=$ zařadit rychlost, ozubené soukolí), innovazione (= inovace), inossidabile
(= nerezavějící), involucro (= kryt, potah); víceslovný termín s in- incidentato macchina $(=$ havarované auto);

inter- předpona disponující významem pevné ohraničenosti nebo přesné specifikace $(8$, s. 53); př́klady: intercambiabile (= vyměnitelný, zaměnitelný); interessante (= zajímavý); interruttore (= vypínač, přerušovač), intervallo (= rozmezí, vzdálenost);

iper- prefix zachovávající si označení nějaké přemíry dané vlastnosti $(8$, s. 55); př́klady: iperdosaggio (= předávkování, vysoká dávka), iperacustico (= nadzvukový), iperconsumo (= vysoká spotřeba), ipertensione (= přetlak);

ipo- prefix vyjadřuje $\mathrm{k}$ danému objektu spíše než rozměry její entitu ( 8, s. 55); př́klad: ipotensione (= nízký tlak);

micro- prefix vyjadřující velikost původního objektu v rádech jednotek $10^{-6}(8$, s. 54); príklady: microelettronica (= mikroelektronika), microchip (= mikročip), microfondere (= odlévat přesným litím);

mini- prefix zmenšující velikost původního objektu zájmu $(8$, s. 54$)$; príklady: miniare (= zmenšit, jemně nakreslit), miniaturistico (= miniaturní), minicalcolatore (= minipočítač), minicomputer (= minipočítač);

neo- prefix jehož neologismy mají význam něčeho nového nebo obnoveného $(8$, s. 54); prríklad: neopatentato $(=$ čerstvý držitel řidičského oprávnění);

s- prefix vyvolávající touhu po zbavení se závislosti na objektu (8, s. 59); př́klady: svitare (= vyšroubovat), sbloccare (= odblokovat);

re- prefix přidávající verbum finitum návrat do původního stavu (8, s. 59); prŕíklady: recuperare (= znovuobnovit), regolare (= ř́́dit);

retro- přepona vyjadřující prostorový zpětný vztah s objektem (8, s. 53); př́klady: retrocedere (= couvat), retromarcia (= zpáteční rychlost), retrovisore (= zpětné zrcátko), retrotreno (= zadní část automobilu);

ri- prefix směřující $\mathrm{k}$ opakování dějového stavu slovesného tvaru (8, s 59); př́klady: ricostruire $(=$ znovu postavit, vyrobit), ribaltare $(=$ převrátit), riciclabile (= recyklovatelný), rifornimento (= natankovat), rimessa (= garáž), rimorchio (= vlek, př́ívěs), ripesa (= akcelerace), risalire (= znovunastoupit);

sopra- předpona odpovídající stavu převyšující standard; prŕklady $(8$, s. 53$)$ : soprammobile (= ozdobný předmět), sopravvento (= výhoda, převaha);

sotto- předpona úzce spojena se stavem nesplňující určitý standard; př́klady: 
sottoprodotto $(=\quad$ vedlejší produkt $)$, sottoconsumo (= podprůměrná spotřeba), sottoascellare (= opěrka podpaží);

sovra- předpona označující stav překračující standard (8, s. 53); príklady: sovraffollato (= přeplněný), sovraccarico (= přetížený);

super- kvalitativní prefix vyjadřující vysoký stupeň vlastnosti substantiva $(8, \quad$ s. 55); příklady: supercomputer (= superpočítač $)$, supercarburante (= pohonná hmota, palivo), superlativo (= nepřekonatelný); víceslovný termín se super- př́klady: superficie frenante (= brzdná plocha), superficie alare (= povrch kř́́del, spoilerů);

\section{Sufixy v italské automobilové terminologii}

Sufix představuje malý slovotvorný segment, jenž se připojuje za slovotvorný základ za účelem vytvoření novotvaru. Českými př́klady z oblasti automobilismu je sufix: -er typický pro výrazy spoiler, boxer, sufix -ovka ve výrazu prevodovka nebo sufix ivost pro substantivum pretáčivost.

-aggine sufix označující nejčastěji negativní lidské vlastnosti (8, s. 45); př́klad: sbadataggine (= nepozornost);

-aggio sufix svázaný $\mathrm{s}$ technicky orientovanými profesními aktivitami (8, s. 43); př́klady: frenaggio (= brždění), vantaggio (= výhoda, náskok);

-aio sufix znamenající většinou povolání nebo řemesla, jejíž základem je spjatost s konkrétní věcí ( 8 , s. 35$)$; př́ílady: operaio (= dělník), chiavaio (= zámečník);

-aiolo sufix, jenž nesou výrazy nízkých neperspektivních zaměstnání nebo neziskových koníčků (8, s. 36); príklad: curvaiolo (= zapálený fanoušek);

-ante sufix jehož slovotvorným základem je většinou substantivum (8, s. 36); př́klady: giornante (= zaměstnanec denní směny), nottante (= zaměstnanec noční směny), casello (= výběrčí mýtného při vjezdu/výjezdu $\mathrm{z}$ dálnic);

-aro sufix spjatý s povoláními, jenž jsou společensky diskutabilní nebo povolání na hranici zákona (8, s. 34); př́klady: panchinaro (= náhradník, náhradní pilot), benzinaro (= zaměstnanec benzínové pumpy);

-ata sufix charakteristický pro slova ve svém obsahu dosahující nějakého cíle $(8$, s. 41); př́iklad: frenata (= zabrždění);

-eria sufix jehož základem je adjektivum označuje ve většině př́ípadů negativní lidské vlastnosti $(8$, s. 46); prríklad: schizzinosaggine (= výběrovost);

-ezza sufix poukazující na uživatelské vlastnosti v automobilém průmyslu $(8$, s. 45$)$; př́klady: autorevoleezza (= spolehlivost), maneggevolezza (= snadná ovladatelnost);

-iere sufix nových specializovaných činností nebo výrazů spadajících do oblasti vojenské terminologie $(8, \mathrm{~s} .36)$; prríklad: autiere (= řidič vojenského automobilu);

-ificare sufix typický pro obecné pojmy zejména z oblasti technicko-vědecké ( 8, s. 49); př́klad: intensificare (= zintenzivnit);

-ista sufix nesoucí význam osoby vykonávající povolání odvozeného ze substantiva $(8$, s. 33); prríklady: camionista (= řidič kamionů), automobilista (= řidič automobilu), buldozerista (= řidič automobilu), gommista (= opravár pneumatik);

-ità sufix zahrnující široké spektrum uživatelsky neopomenutelných vlastností automobilu (8, s. 45); príklady: utilità (= užitečnost, praktičnost), vastità (= prostornost), viabilità (= sjízdnost silnic), visibilità $(=$ viditelnost), velocità (= rychlost);

-izzare sufix charakterizující náročnou technickou změnu často spjatou s technických vývojem a pokrokem (8, s. 48); př́klady: semiautomatizare $(=$ poloautomatizovat $)$, automatizzate (= automatizovat);

-mento sufix označující tendence náhlých změn nebo z výrazů specifického zakončení $(8$, s. 39); príklady: gareggiamento (= závodění), allenamento (= trénink);

-nte sufix tvořící substantizovaný tvar neologismu z přítomného př́icestí $(8, \mathrm{~s} .31)$; prríklady: conducente (= řidič), aiutante (= pomocník), esercente (= vedoucí);

-tore sufix s vysokou frekvencí vyjadřující lidskou činnost ve formě substantiva odvozeného z tvaru verbum finitum (8, s. 30); prríklady: vincitore (= vítěz), verniciatore, laccatore (= lakýrník), gareggiatore (= závodník), arredatore (= návrháŕ potahů), montatore (= mechanik, montér);

-tura sufix vážící se k technicky orientovaným výrazům (8, s. 42); př́klady: smaltarura, verniciatura, laccatura (= lakování), tornitura (= soustružení), saldatura (= svařování); víceslovný termín s -tura laccatura ad immersione (= lakování namáčením), laccatura a fuoco (= lakování s vypalováním), laccatura a spruzzo (= lakování stř́káním);

-zione sufix vystihující mikrosituace substantivem odvozeným z verbum finitum $(8$, 
s. 38); př́klady: riattazione (= renovace), disposizione (= uspořádání), prestazione (= výkon), direzione (= ředitelství, směr jízdy), accelerazione (= akcelerace, zrychlení), combustione (= spalování);

\section{Vyjádření systémových vztahů přídavnými jmény}

Kapitola dokumentuje jednoslovné termíny zoblasti automobilismu a jejich využití v tvorbě víceslovných termínů. Jednoslovné termíny velmi často už přesně nevystihují daný termín i když s ním z velké části souvisejí a vliv závislosti si udržují. Nejednodušším způsobem, jak obohatit systém termínů daného vědního oboru a respektovat pravidla pro jednoduchou osvojitelnost, jednoznačnost a přesnost je vznik terminologického adjektiva. Termín tím ztrácí požadavek na krátkost, který však někdy nesprávně kompenzujeme vynecháním adjektiva, a tím se dopouštíme podáním nepřesné nebo zkreslené informace.

albero (= hřídel) albero motore (= motorový hř́idel), albero di comando (= hnací hř́ídel), albero portaingranaggi $(=$ hnací hřídel převodovky), albero a camma (= vačkový hř́ídel), albero a monovella (= klikový hř́ídel), (11, s. 170);

ammortizatore (= tlumič) ammortizatore ad olio (= olejový tlumič), ammortizare di scario (= tlumič výfuku), (12, s. 87);

asse (= náprava), asse anteriore (= přední náprava), asse motore (= hnací náprava); asse non portante (= odlehčená náprava), $(9, \mathrm{~s} .28)$;

cambio (= převodovka) cambio sequenziale (= sekvenční převodovka), cambio mano (= manuální převodovka), cambio sul volante (= řazení pod volantem), cambio dell'ollio (= výměna oleje), cambio di marcia (řazení rychlostních stupňů), $(9$, s. 51);

carrozeria (= karosérie) carrozeria portante (= samonosná karosérie), carrozeria aerodynamica (= aerodynamická karosérie), carrozeria cabriolet (= otevřená karosérie), (11, s. 170);

cilindro (= válec) cilindro motore (= motovový válec), (10, s. 160);

frenatura (= brzda) disko del freno (= kotouč brzdy), pedale del freno (= brzdový pedál), azione frenante (= brzdný účinek), freno a tamburo (= bubnová brzda), freno a mano (= ruční brzda), $(9$, s. 130);

motore (= motor) motore noc compressore (= motor s přeplňováním), motore noc cilindri a $V$ (motor s válci do $\mathrm{V}$ ), motore di automobile (automobilový motor), motore anteriore (motor vpředu), motore posteriore (motor vzadu), motore a due cilindri (=dvouválcový motor), $(9$, s. 190);

pistone (= píst) pistone valvolato (= ventilový píst), anello per pistone (= pístní kroužek), motore a pistoni (= pístový motor), (10, s. 688); valvola (= ventil) valvola aspirante (= sací ventil), valvola di spurgo (= výfukový ventil), (9, s. 317);

\section{Závěr}

Studie pojednávající o problematice obecných trendů v oblasti italské automobilové terminologie se snaží přispět k neustálému hledání a rozvoji nových netradičních př́istupů k vyučovacímu procesu. Pozitivně může ovlivnit i cestu k posilnění postavení italštiny z pohledu integračního jazyka EU. Dokazuje nám, že i Italština může sehrát klíčovou roli z pohledu vzniku a vývoje automobilové terminologie. Svými trendy působí nejen v segmentu vrcholového autosportu a sportovních silničních automobilů, ale ovlivňuje i běžný automobilový průmysl všech cenových kategorií. V praxi může sloužit lingvistům $\mathrm{k}$ tvorbě slovníků z oblasti italského automobilového vědeckotechnického pojmosloví a vzniku nových kompozitních tvarů. Vědecká stat' nastiňuje možnost propojení a upevnění mezipředmětových vazeb s využitím lingvistických prvků v obecně technickém předmětu.

\section{Literatura}

(1) STOFFA, J. Terminológia v technickej výchove. 2. upr. vyd. Olomouc : VUP, 2000. 161 s. ISBN 80-244-0139-8.

(2) LAVRINČÍK, J. O jednom netradičním způsobu motivace žáků $\mathrm{v}$ hodinách IKT prostřednictvím zájmu o F1. In Infotech 2007 : Moderní informační a komunikačni technologie ve vzdělání. 1. vyd. Olomouc : Votobia, 2007. Obecné otázky využití IKT ve vzdělání. s. 153156. ISBN 978-80-7220-3.

(3) STOFFA, J., STOFFOVÁ, M. Porovnanie vyjadrenia malej miery, absencie a nadbytku v slovenskej a spanelskej terminoligii pomocou systémových prefixoidov a sufixoidov. In Didmattech 2007. 1. vyd. Olomouc : Votobia, 2007. s. 806-812. ISBN 80-7220-296-0.

(4) LAVRINČÍK, J. Projevy obecných trendů v oblasti automobilové techniky značky Ferrari. In Trendy ve vzdělání 2008 : Informační technologie a technické vzdělání. 1. vyd. 
Olomouc : Votobia, 2008, s. 150-153. ISBN 978-80-7220-311-6.

(5) STOFFA, J. Systémové prvky v materiálovednej terminologii. In Didmattech 2007. 1. vyd. Olomouc : Votobia, 2007. s. 800805. ISBN 80-7220-296-0.

(6) HARTMANNOVÁ, V., HARTMANNOVÁ, D. Pravidla českého pravopisu. 1. vyd. Olomouc : FIN, 1994. 607 s. ISBN 80-8557244-3.

(7) FERRARI, E. Mé strašné radosti. 1. vyd. Praha : Mladá Fronta, 1970. 180 s. [ISBN nemá].

(8) ŠTICHAUER, P. Tvoření slov v současné Italštinè. 1. vyd. Praha : Karolinum, 2007. 127 s. ISBN 978-80-246-1347-5.

(9) JANEŠOVÁ, J., POLVERARI, A. Italsko český a česko - italský slovnik. 1. vyd. Brno : Leda, 2006. 896 s. ISBN 80-7335-064-5.
(10) Odborný slovník Technika v 11 jazycích. 1. vyd. Praha : Grada Publishing, 2003, 2003. 1135 s. ISBN 80-247-0779-9.

(11) LABAN, B. Historie automobili Ferrari. 1. vyd. Praha : Slovart, 2003. 192 s. ISBN 807209-481-5.

(12) BRAUN, P. Ferrari. 1. vyd. Praha : Computer Press, 2004. 125 s. ISBN 80-7226662-4.

Mgr. Jan Lavrinčík, DiS.

Katedra technické a informační výchovy

Pedagogické fakulta UP

Žižkovo nám. 5

77140 Olomouc, ČR

Tel. +420 585635813

E-mail: nobilis.felis@seznam.cz

Www pracovišstě: www.kteiv,upol.cz 